\title{
Consumers' willingness to pay for organic beef: Evidence from Dhaka City
}

\section{P. K Sarma and S. K. Raha}

Senior Scientific Officer, BAU Research System and Department of Agribusiness and Marketing, Bangladesh Agricultural University, Mymensingh-2202, Bangladesh E-mail: paresh.baures@bau.edu.bd

\begin{abstract}
This study was carried out in order to identify consumers' willingness to pay a price premium for organic beef in Dhaka city of Bangladesh during the period July-December 2015. The research surveyed 180 consumers using semistructured questionnaires to examine consumer's perception about organic beef and assess their willingness to pay for beef. The study revealed that all respondents are willing to pay price premium for organic beef. Consumers are willing to purchase organic beef because these beef are free of pesticides, chemical, drug, steroid, etc. A health conscious is one of the main determinants of willing to pay followed by consumer perception and quality towards the organic beef. A total of $41 \%$ of the consumers are willing to pay $0-5 \%$ price premium, whereas $30 \%$ are willing to pay up to $10 \%$ price premium. About $19 \%$ of the respondents feel the extra cost for organic beef is reasonable, while $10 \%$ considered it too high. The survey also suggested that the consumption of organic beef is increasing; however, develop production method, slaughtering process, processing, packaging, labeling, and innovations hallal certification from Islamic foundation are needed to stimulate further demand. It was also found that only some groups of consumers are willing to pay the premium necessary for alternative methods of production.
\end{abstract}

Keywords: Consumers preference, Organic beef, Price premium, WTP

\section{Introduction}

The role of organic agriculture in providing food and income is now gaining wider recognition (Van Elzakker et al 2007). The market of organic products is growing as the number of people willing to eat organic food and pay premium price is increasing. The future of organic agriculture will, to a large extent, also depend on consumer demand and their motive for paying extra price for organically grown food. Thus, a consumer-oriented approach to understanding the market for organic products is important for pursuing better management of organic farming. It is also important to understand consumer decisionmaking regarding organically produced foods and seek strategies about how consumption can be promoted. Self employment and income generating activities are continuing and mainly done by personal interest or by the help of government and non-government organization through different cattle fattening program in Bangladesh. It can play an important role in reducing rural poverty. As organic production is largely consumer driven, therefore, it is important to take into account consumer attitudes in selecting the appropriate breeds and strains for organic beef. One of the most striking consumer trends in recent years has been the increasing demand for natural and healthy foods where also ethical issues are taken into consideration. Safety has also become a very important issue of concern in modern food production, prompted by concerns about hormones, bovine spongiform encephalopathy, antibiotics, dioxin contamination of feed, etc. Corsi et. al. (2002) shows that consumers' WTP is quite high, thus suggesting that organic beef might gain an appreciable market share. Napolitano et. al. (2009) found that consumers' behaviors and attitudes toward organic meat were tested through their study of the effect of information about organic farming practices on product linking and consumer willingness to buy organic beef and pay the extra production cost. Consumers are prepared to spend more for organic beef, thus indicating that reliable information about the organic farming system may markedly increase consumer willingness to pay. A review by Yiridoe et al. (2005) found that food safety and nutritive value were rated as very important factors by $80 \%$ of consumers who usually buy organic food tends to be more concentrated about food safety and nutritive value than price. Various importing companies are reported to want safe beef without growth hormones, because of consumer concerns. Organic beef production is a means of food production with a large number of rules directed towards a high status of animal welfare, care for the environment, restricted use of medical drugs and the production of a healthy product without residues e.g. drugs inorganic fertilizer, pesticides, growth stimulating substances like hormones, steroids, feed 
additives, etc (Kijlstra and Eijck, 2006). In Bangladesh, Islam et. al. (2012) found that beef cattle are fattened allegedly by unscrupulous cattle traders ignoring the scientific formula prescribed by Livestock Department. The information related to organic beef cattle production by the farmers in Bangladesh is very limited. No attention been yet paid in respect of using growth promoting steroids and feed additives in small scale cattle farming system. Therefore, the present study was undertaken to know the present status of consumers' WTP for organic beef in Bangladesh.

The aim of this study is to shed light on consumers' perceptions about organic beef and their willingness to pay for organic beef. More specifically, the objectives of the study are:

1) To increase understanding of consumers' awareness, attitude and perceptions towards organic beef,

2) To assess consumers' willingness to pay (WTP) for organic beef, and

3) To identify factors influencing of WTP for organic beef.

\section{Theoretical framework}

Many consumers seek food safety and are willing to pay higher prices for "healthy or nutritive products" since they increase their utility level, reducing, health risks at the same time. However, they are unable to ascertain food safety before purchase, being this the most important constraint to economic efficiency in the production and marketing of food safety. Since some of these health risks benefits are hard to assess, a method commonly applied to determine food safety benefits is estimating consumers' willingness to pay for safer and better quality food (Goldberg and Rosen, 2005). Along these lines, the notion of willingness to pay could be defined as the sum of money representing the difference between consumers' surplus before and after adding or improving a food product attribute. Van Ravenswaay and Wohl (1995) and Halbrendt et al. (1995) introduced models that estimate consumers' willingness to pay when adding or enhancing a given quality attribute. In general, the willingness to pay a price premium decreases as the price premium increases, consistent with the law of demand. In consumer behavior theory, consumers make their own decisions to balance the marginal health utility and marginal price of one unit of qualityfood products. In this research, a simple framework was used to analyze consumer behavior towards organic beef, which includes the willingness to pay a price premium. Consumers decide whether to buy a beef or not based on three main aspects: Knowledge, Attitude and Intention. Knowledge about organic beef and their benefits influences their willingness to pay for beef. Knowledge of consumer is affected by type and quality of information made available to consumers. Advertisement, quality packaging, labeling and hallal certification are play pivotal role in knowledge enrichment. Once a consumer is ready to buy, the next step is to see how much he or she is willing to pay for organic beef. Purchase behavior reflects the real WTP and the consumer gains positive or negative experiences which will reversely affect consumers' WTP in future. Knowledge and awareness have respectively direct and indirect effects on attitudes toward consumer to choose the products, and the willingness to pay a price premium, so they are important factors determining the demand. Thus, awareness and knowledge about organically rearing cattle are critical in the consumer willingness to pay more for the organic beef.

Similarly, the framework presented in Fig. 1 reflects the factors affecting consumers' attitude and willingness to purchase. Consumers' willingness to purchase is affected by exogenous factors like processing, packaging, certification and labeling and consumers' knowledge and awareness about the beef. If an individual cannot clearly differentiate between two alternative products, a price premium on the organic beef can confuse and/or affect the individual's purchasing decision. Consumers' education, occupation, household size along with product attributes affects their attitude and preference to buy the products. These factors further depend on consumers' household income and beef price to make a decision for purchase. 


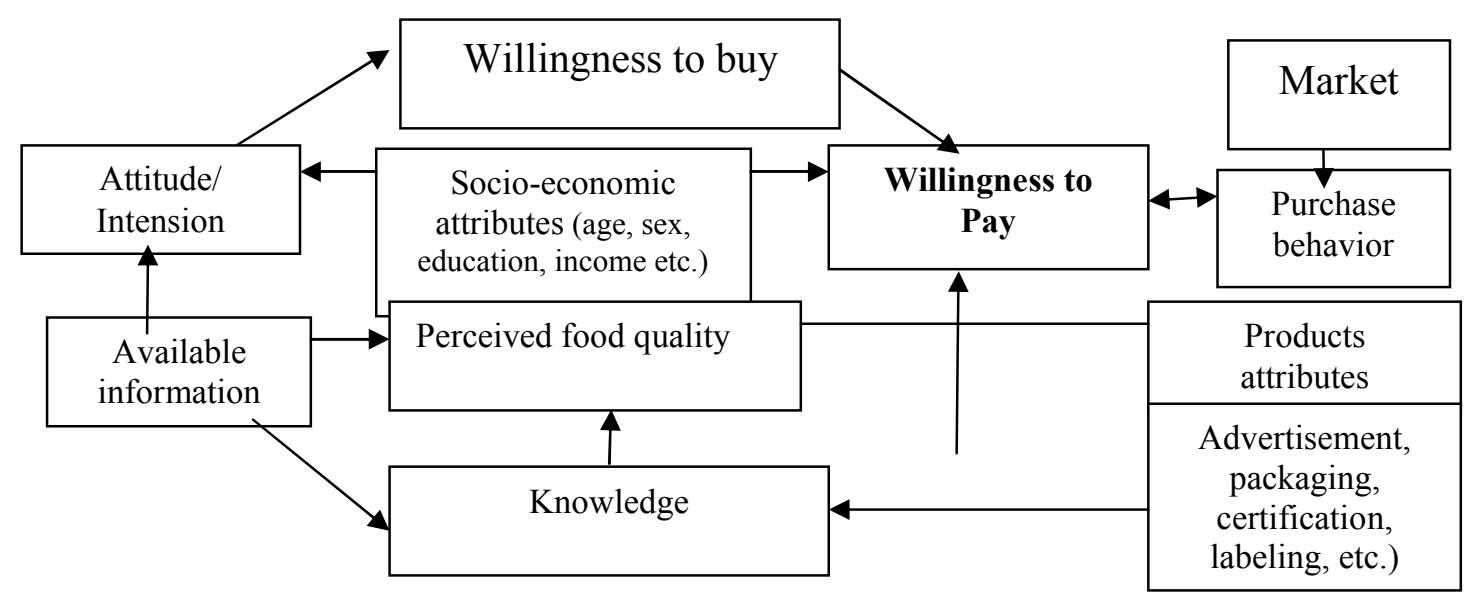

Fig. 1. Framework reflecting consumer behavior towards organic beef (adopted from Millock (2002) and BontiAnkomah and Yiridoe (2006)

\section{Materials and Methods}

The study was carried out in Dhaka mega city of Bangladesh. The Dhaka city was chosen for the high urban population and for the fact that a considerable amount of the commercial beef cattle are come from all over the country. Conveyance sampling technique was used in the study and a total of 180 sample was collected from supermarkets in Dhaka city by pre-determine interview schedule. Descriptive statistics was used to analysis of consumers' awareness, preference and perception, etc while probit regression model was used to analysis the factors influencing consumers' willingness to pay for organic beef.

The model is specified as consumers' willingness to pay for organic beef is:

WTP $_{\mathrm{i}}{ }^{*}=\beta_{0}+\beta_{1}$ Bids $+\beta_{2}$ Educ $+\beta_{3}$ Age $+\beta_{4}$ Gend $+\beta_{5}$ Price $+\beta_{6}$ Sour $+\beta_{7}$ Incm $+\beta_{8}$ Know +

Where:

$$
\beta_{9} \text { Perc }+\beta_{10} \text { Hhsz }+E_{i} \text {. }
$$

WTP $_{\mathrm{i}}^{*}=$ Willingness to pay for organic beef information (Yes $=1 ; 0=\mathrm{No}$ )

Bids $=$ Random amount the consumer will be asked to pay in BDT.

Educ $=$ Level of education of respondents in years

Age $=$ Age of consumers in years

Gend $=$ Sex of the respondents $($ Female $=1$, Male $=0)$

Price $=$ Unit price of beef

Sour $=$ Source of beef (Registered $=1$, Unregistered $=0$ )

lincm $=$ Income of consumers in BDT.

Know $=$ Knowledge of organic beef information(Aware $=1$, Not aware $=0$ )

Perc $=$ Perception of consumers on organic beef information $(1=$ No chance of health problem, $0=$ chance of health problem)

Hhsz $=$ Household size in number

$\mathrm{E}_{\mathrm{i}}=$ Error Term

\section{Results and Discussion}

The descriptive statistics discusses consumer's awareness, perceptions and attitudes, that lead to the willingness to pay (WTP) for organic beef in following sub-heading. The results of the attributes consumers prefer and use in their purchasing decision are discussed in sub-headings the results of the analyses on the factors that influence the consumers' preferences and willingness to pay for beef product attributes are presented respectively. 


\section{Consumer awareness about organic beef}

The perception and understanding about organic beef varies depending on the type of consumer. The frequency analysis results of consumers' awareness towards beef are presented in Table 1. The results show that $51.67 \%$ of the respondents have heard or read about organic beef and $65 \%$ of them have heard/read about illness caused by the use of steroid for cattle fattening and only $21.67 \%$ of the respondents have experienced the illness caused by the beef. The results also indicated that less than $39.44 \%$ of the respondents were aware of purchasing organic beef for food safety. This might be due to lower percentage of them experiencing the illnesses caused by beef. Most of the respondents gained the information from newspapers $(30.69 \%)$, television $(40.59 \%)$, radio $(5.94 \%)$, doctor $(10.89 \%)$ and friends $(4.95 \%)$. This finding is similar to the study by Buzby et al., (1995) in which results showed that $70.1 \%$ of the respondents mentioned newspaper articles as the main source of information on food safety. In general, this indicates that a very high percentage of respondents are aware of food safety related with organic beef.

Table 1. Consumers' awareness towards organic beef

\begin{tabular}{clcc}
\hline SI. & Statements & \multicolumn{2}{c}{ Respondents' opinion } \\
\cline { 3 - 4 } No. & & Yes & No \\
\hline 1 & Heard/read about organic beef? & $93(51.67 \%)$ & $87(48.33 \%)$ \\
2 & Heard/read about illness caused by the use of steroid for & & \\
& cattle fattening? & $117(65.00 \%)$ & $63(35.00)$ \\
3 & Experience illness caused by beef? & $39(21.67 \%)$ & $141(78.33 \%)$ \\
4 & Aware of purchasing organic beef for food safety? & $71(39.44 \%)$ & $109(60.56 \%)$ \\
5 & Source of information about convention and organic beef & $101(56.11 \%)$ & $79(43.89 \%)$ \\
& (a) Newspapers & $31(30.69 \%)$ & $14(17.72 \%)$ \\
& (b) Magazines & $4(3.96 \%)$ & $7(8.86 \%)$ \\
& (c) Radio & $6(5.94 \%)$ & $19(24.05 \%)$ \\
& (d) Television & $41(40.59 \%)$ & $21(26.58 \%)$ \\
(e) Friends & $5(4.95 \%)$ & $10(12.66 \%)$ \\
(f) Doctor & $11(10.89 \%)$ & $6(7.59 \%)$ \\
(g) Someone in household & $3(2.97)$ & $2(2.53 \%)$ \\
\hline
\end{tabular}

Source: Field survey 2015

The results show that the knowledge and awareness level among the surveyed consumers are fairly good but not adequate. Hence, awareness raising programmes among existing and new consumers on organic products could be an effective mechanism for the promotion of organic products in future.

\section{Consumers' attributes of willingness to pay for organic beef}

Consumers' attributes are method of rearing cattle, price, fat content, cholesterol, breed, artificial ingredients, safety, traceability, place of origin. For instance, Feuz and Umberger (2001) examined consumer willingness to pay for flavor in beef. It was reported that consumers were willing to pay a slightly higher price for the more marbled choice beef than the lower marbled select beef. In addition, consumers were willing to pay more for organic beef than conventional beef. Table 2 shows estimates for meat attributes and their influence on willingness to pay more beef certified as produced locally or regionally. It shows overall significance of the model $(p=0.001)$, i.e., at least one or all of the meat attributes jointly explain the dependent variable. WTP more for beef or goat meat certified as produced locally or regionally is significantly affected by perception of being safe to consume (safety); no difference between the safety of locally or regionally produced meat and non-locally or regionally produced meat (no difference in safety), and hygiene of meat, respectively, $p=0.056, p=$ 0.032 , and $p=0.003$. For safety, the stronger the perception that beef certified as produced locally or regionally is safe to consume, the more the willingness to pay more for it. 
Table 2. Product attributes and their influence on willingness to pay for organic beef

\begin{tabular}{lcc}
\hline Variable & $\beta$ & $P$ \\
\hline Safety & $0.252^{*}$ & 0.056 \\
No Difference & $-0.188^{* *}$ & 0.032 \\
Availability & 0.232 & 0.112 \\
Affordability & -0.145 & 0.281 \\
Quality & 0.043 & 0.783 \\
Desirability & 0.170 & 0.283 \\
Hygiene & $-0.261^{* * *}$ & 0.003 \\
Chi-square & $25.923^{* * *}(P=0.001)$ & \\
Nagelkerke R2 & 0.062 & \\
\hline
\end{tabular}

Source: Author estimation 2015

Note: ${ }^{* *}$ Significant at $1 \% ;{ }^{* *}$ Significant at $5 \%$ and ${ }^{*}$ Significant at $10 \%$ level

Similarly, for no difference, the stronger the perception that there is no difference between the safety of beef certified as produced locally or regionally and beef non-locally or regionally produced, the less the willingness to pay more for the former. Also, for hygiene, the stronger the perception that beef certified as produced locally or regionally is hygienic and wholesome (hygiene), the less the willingness to pay more for it. The latter result may be due to the fact that consumers expect meat sold to be hygienic and wholesome anyway so they do not expect to pay more for this attribute. Regarding safety, the finding is comparable to those found by Dobbs (2015), Lieu et al. (2013), and Latvala (2010). They reported that consumers were willing to pay more for safety, and safety had a significant effect on willingness more for livestock products. Availability of product, affordability of product, quality of product, and desirability of product were statistically insignificant. In addition, availability, quality, and desirability, although not significant, positively influenced willingness to pay more for beef certified as produced locally or regionally. Contrarily, affordability negatively influenced willingness to pay more; price may be a sensitive attribute.

\section{Consumers' preference for organic beef}

Consumer preferences for beef product attributes have received little attention in Bangladesh. However, studies have shown that during animal slaughter, procedures for humane slaughter, personnel involved in post-slaughter meat handlings are some of the critical factors considered to influence consumer preference for beef in Bangladesh. Religious considerations have been found to be one of the key factors influencing beef slaughter and preferences. Consumers of beef also apparently have their personal criteria for beef preference and purchase which varies across individual consumers in terms of their demographic characteristics like age, education, income and perception of food safety. These criteria used by consumers must be investigated to make sure the safety of consumers is assured.

\section{Consumers' willingness to pay for organic beef}

The result showed that in case of product availability, all the consumers are willing to pay higher prices for organic beef. The price premium is ranging from $0 \%-20 \%$ depending upon the products and consumers' willingness to buy.

The consumers survey revealed that $41 \%$ of the interviewed consumers $(\mathrm{N}=180)$ are willing to pay up to $5 \%$ price premium compared with non-organic. Similarly, $30 \%$ of the consumers like to pay between 6 $10 \%$ price premiums. In comparison, $19 \%$ of consumers are WTP about $11-20 \%$ price premium and only $10 \%$ of consumers reported they are WTP more than $20 \%$ price premium for any organic beef (Fig. 2 ). 


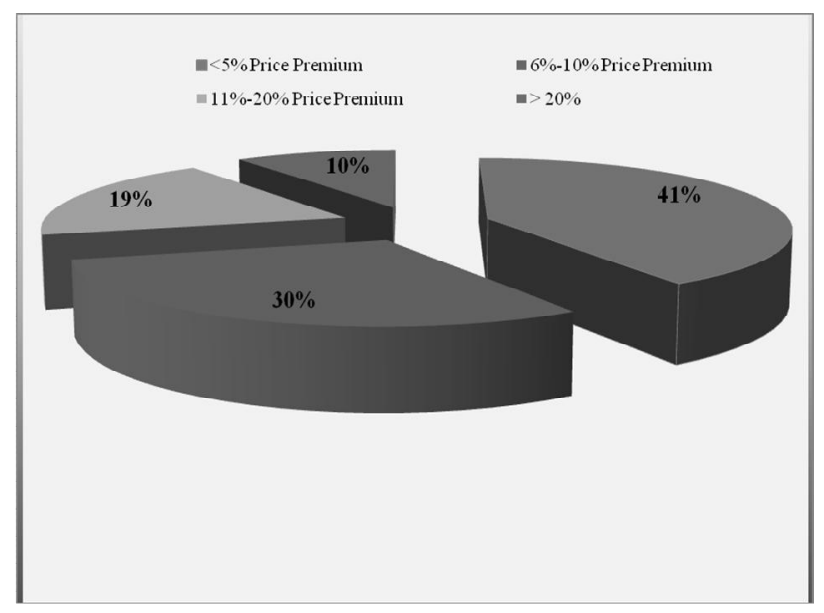

Fig. 2. Consumers' WTP premium price for organic beef

Similar study by Asadi et al. (2009) in Iran reported that majority of the consumers are not willing to pay a price premium higher than $20 \%$. The similar study by Millock (2002) in Denmark reported that, $35 \%$ of the consumers are willing to pay more for any type of organic products compared to $18 \%$ of consumers who are not willing to pay for all kind of products. In this case, organic products also depends on the consumers preference which product to buy or not. Menon (2008) on his paper mentioned that the organic product are gaining price premium from $5 \%$ to as high as $60 \%$ in some products.

\section{Consumers' perception about the price of organic beef}

In general, consumers' perceptions about the current price of organic beef are very positive. Nearly $49.44 \%$ of the consumers reported that the price of organic beef compared with conventional one is reasonable. In the recent days, organic beef compete with conventional alternatives in the market. Consumers feel that the price depends on the market and the specific goods. Majority of the consumers reported that fresh organic beef have higher price compared to conventional beef.

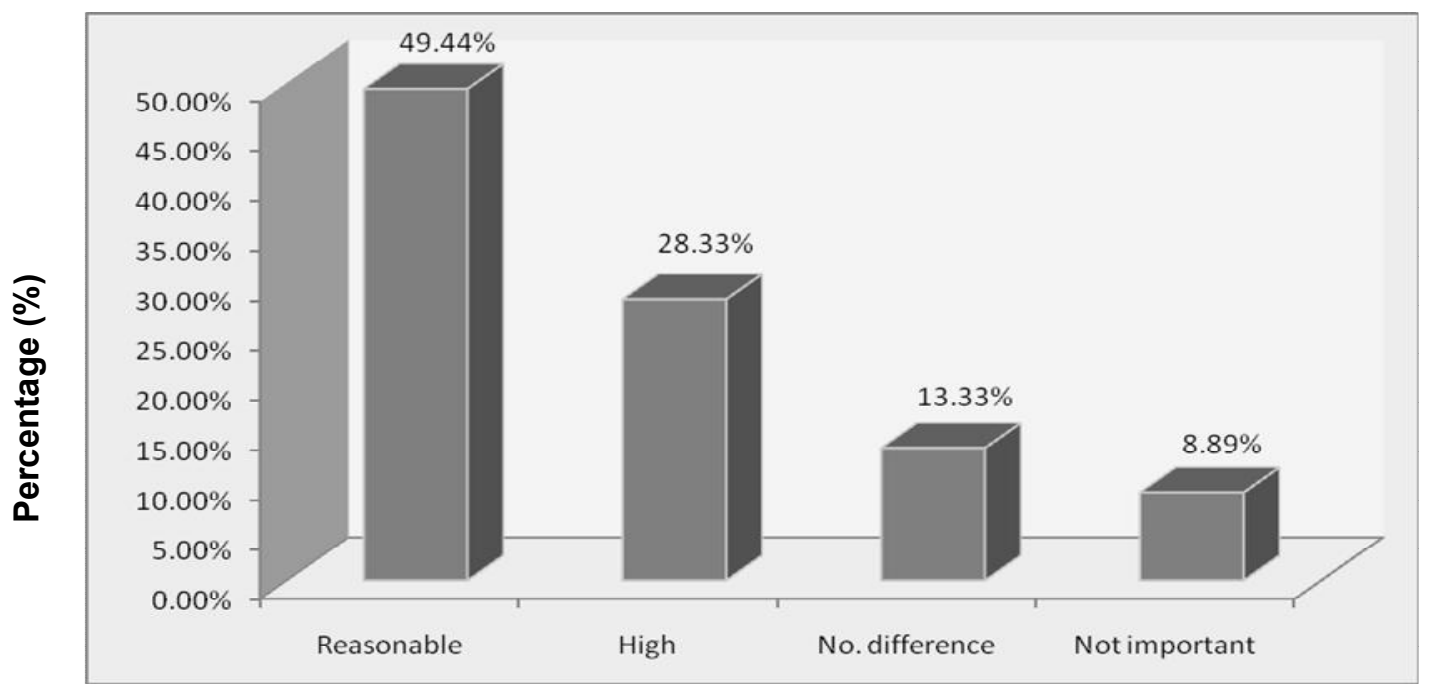

Fig. 3. Consumers' perception about price of organic beef $(\mathrm{N}=180)$ 
About $13.33 \%$ consumers' reported that no price difference between organic and conventional beef due to lack of awareness of food safety and $28.33 \%$ consumers perceived that the average price of organic beef is higher compared to conventional ones (Fig. 3). The comparison with food safety by the consumers might be the main reason for their perception that the organic beef expensive. The study findings further showed that despite of having higher price compared to conventional alternatives, many consumers continue to buy organic beef. This is further supported by the study findings like consumers who usually buy organic beef were more concerned about food safety than price.

On the other hand, the segregated data showed that those who used to go for Dhaka city think that organic products are higher in price compared with inorganic beef. Fifty percent of the meat buyers at the beef perceived that the price is higher as against $31.37 \%$ of government officials, $21.57 \%$ for teachers, $25.49 \%$ of private service holders and $9.80 \%$ of businessmen (Table 3 ). Various study supported that consumers will give second priority to the price of the products and they always look for the quality organic food. They feel that the price of organic food becomes the cost of investment in good health (Aryal, 2008, Menon 2008, Sandalidou et.al, 2002).

Table 3. Consumers' perception about the price of organic beef for different professionals

\begin{tabular}{lcccc}
\hline Profession & Reasonable & High & Not important & No difference \\
\hline Teachers & 20 & 11 & 3 & 3 \\
& $(22.47 \%)$ & $(21.57 \%)$ & $(12.50 \%)$ & $(18.75 \%)$ \\
Private service holder & 13 & 13 & 4 & 2 \\
& $(14.61 \%)$ & $(25.49 \%)$ & $(16.67 \%)$ & $(12.50 \%)$ \\
Government service & 24 & 16 & 2 & 3 \\
holder & $(26.97 \%)$ & $(31.37 \%)$ & $(8.33 \%)$ & $(18.75 \%)$ \\
Businessmen & 21 & 5 & 5 & 2 \\
& $(23.60 \%)$ & $(9.80 \%)$ & $(20.83 \%)$ & $(12.50 \%)$ \\
Self-employee & 7 & 3 & 8 & 3 \\
Beef buyers for food & $(7.87 \%)$ & $(5.88 \%)$ & $(33.33 \%)$ & $(18.75 \%)$ \\
processing & 4 & 3 & 2 & 3 \\
\hline Total & $(4.49 \%)$ & $(5.88)$ & $(8.33 \%)$ & $(18.75 \%)$ \\
& 89 & 51 & 24 & 16 \\
& $(100.00 \%)$ & $(100.00 \%)$ & $(100.00 \%)$ & $(100.00 \%)$ \\
\hline
\end{tabular}

Source: Field survey 2015

\section{Factors affecting consumers' willingness to purchase for organic beef}

A probit regression model was used to identify socio-economic factors likely to affect consumer WTP for organic beef. The result of determinants of consumers WTP for organic beef in Dhaka city is presented in table 4. The model produced a good fit of the data with the Chi-square value of the regression being statistically significant $(P<0.01)$ while the Resudo $R^{2}$ indicates that about $65 \%$ of the variations in the dependent variable (WTP) is explained by the independent variables. Thus, from the diagnostic tests, it shows that the Probit regression model fits the analysis. Among the regressors, gender of consumers, knowledge of consumers, education level of consumers, income of consumers and source of purchase of organic beef are significant factors that influence consumers WTP for organic beef consumption. Gender is positively and significantly $(P<0.01)$ influence, consumers WTP for food safety information in protein organic beef. The result implies that female consumers relative to male counterpart are more likely to pay for food safety information in protein of organic beef. The marginal effect result shows that consumers' WTP for food safety information increases by $(0.012 \%)$. Knowledge of food safety information positively, and significantly $(P<0.05)$ influences consumers' WTP for food safety information. Consumers' awareness of food safety information increases WTP by $1.05 \%$. The estimated coefficient for education was positive and significant $(p<0.05)$. The positive sign on education indicated that those respondents with a higher level of education were WTP more for organic beef. The marginal effect indicated that a unit increase in the number of years spent in school increased the probability that consumers WTP for organic beef by $1.01 \%$. It also believed that education favours positive attitude towards change. 
Table 4. Probit regression of the factors influencing willingness to pay for organic beef

\begin{tabular}{lccc}
\hline Variables & Coefficient & Standard error & Marginal effect \\
\hline Consumers age & 0.2852 & 0.3915 & 0.4121 \\
Gender (Sex) & $0.9521^{* * *}$ & 0.3211 & 0.1254 \\
Awareness & $0.5236^{* *}$ & 0.8492 & 1.0541 \\
Household size & 0.2566 & 0.1832 & 0.0051 \\
Years of education & $1.2892^{* *}$ & 0.6834 & 1.0114 \\
Income & $0.9956^{* * *}$ & 0.2141 & 0.3241 \\
Average price & -0.8432 & 0.5244 & 0.3111 \\
Source of purchase & $0.9452^{* *}$ & 0.3721 & 0.0211 \\
Perception of cattle breed & 0.3121 & 0.4186 & 0.0821 \\
BIDS & 0.41228 & 0.510 & 0.8111 \\
Constant & $0.1884^{* *}$ & 0.0915 & $0.0251 \mathrm{~s}$ \\
Log-likelihood ratio $=$ & $-53.50^{* *}$ & & \\
Chi squared $=$ & $24.59^{* *}$ & & \\
Resudo $R^{2}$ & 0.647 & & \\
\hline
\end{tabular}

Source: Author estimation 2015

Note: ${ }^{* *}$ Significant at $1 \%{ }^{* *}$ Significant at $5 \%$ and ${ }^{*}$ Significant at $10 \%$

This findings is in similar with Huang (1993) who found out that more educated consumers were WTP more for organic products and also consistent with Du Toit and Crafford (2003) that showed that respondents with a higher level of education WTP to purchase organic food. Source of purchased of organic beef positively and significantly $(P<0.05)$ influence WTP for organic beef. The effect of awareness on WTP was positive and significant, which is indicates an increase in awareness on organic beef increased the probability of WTP by $5.9 \%$. Source of purchased beef increases consumer WTP by $0.02 \%$. Other variables included in the model (Age of consumers, household size, average price, bids and perception of cattle breed do not significantly influence consumers WTP for food safety information in organic beef). For instance, perception of label for organic beef consumers is low.

Also, average monthly mean income and WTP are directly related. An increase in the consumer's income is expected to increase his willingness to pay for beef since he is now able to afford the little bit expensive conventional beef compared with organic beef. The findings are in line with those who reported that WTP for healthy food and respondents' socio-economic characteristics are positively related. The results further reveal that distance to organic beef sales outlets and WTP are negatively linked.

\section{Conclusion and Recommendation}

Consumers are becoming more aware of the quality attributes of organic beef found in the market and are choosing beef that closely match their testes, preferences, price and food safety etc. Consumers' perceptions and beef attributes tend to influence WTP premium for organic beef. They are willing to pay price premium for organic beef which can be viewed as the cost of investment in human health. Knowledge and awareness about organic beef can affect attitudes and perceptions about the beef and, ultimately, buying decisions of the consumers. Consumers' willingness to purchase is influenced by limited and erratic supply, higher price of the beef. Most important factors that influence on WTP for organic beef are their concerned issues (price or safety and quality), education, income, price, awareness, cattle breed and household size for food safety and quality assurance. Consumers' perceptions and beef attributes are significant determinants of WTP for safe and high quality beef products. This study will contribute quantitative information on the consumers' WTP, a price premium for organic beef and consumers' attitudes towards and perceptions of organic beef. In turn, higher prices for organic beef will allow rural farmers to invest more in sustainable organic cattle farming technologies such as nets used as physical barriers to growth promoter and steroid. 
Finally, the study showed a positive willingness to purchase organic beef and consumer preference for beef produced organically relative to those produced following conventional methods. These results may provide important information about beef attributes to agribusiness entrepreneur and farmers as a way to identify new market segments.

\section{Acknowledgements}

The authors are thankful to the beef seller, consumers, employees of supermarkets and different actors in the study areas who participated in the study. The authors have also thankful to anonymous reviewers who gave him valuable comments and suggestions to improve the content of the article.

\section{References}

Asadi, A., Akbari, M., Sharifazadeh, A. and Hashemi, S.M. 2009. Analysis of Factors Affecting Agricultural Organic Products Diffusion among Consumers: Perception of Extension Workers. World App. Sci. J. 6 (3): 331-338.

Aryal, K.P. 2008. General perceptions of producer, traders and consumers about organic products in Kathmandu valley. In P. Chaudhary; K. Aryal and D. Tharu (ed.). Proceedings of International Workshop on Opportunities and Challenges of Organic productsion and Marketing in South Asia, NPG, p.120-124. Kathmandu, Nepal.

Bonti-Ankomah, S. and Yiridoe, E.K. 2006. Organic and conventional food: A literature review of the economics of consumers' perceptions and preference. Final Report. Organic Agriculture Centre of Canada. Nova Scotia Agricultural College, truro, Nova Scotia, Canada.

Buzby, J., Ready, R. and Skees, J. 1994. Contingent valuation in food policy analysis: A case study of a pesticide-residue risk reduction. J. of Agric. and App. Econ., 27(2): 613-625.

Buzby, J.C., Skees, J.R. and Richard, C.R. 1995. Using Contingent Valuation to Value Food Safety: A case of Grapefruit and Pesticides Residues. In Valuing Food Safety and Nutrition, ed. Julie A. Caswell, pp 219-256. Colorado: Westview Press

Corsi, A., and Novelli, S. 2002. Consumers' Willingness to Pay a Price for Organic Beef Meat, paper presented at the 10th EAAE Congress, Zaragoza, 28-31 August.

Dobbs, L.M. 2015. Tennessee consumers' willingness to pay for beef produced in Tennessee." Master's thesis, University of Tennessee, Knoxville, Tennessee. Retrieved on February 5, 2015 from http://trace.tennessee.edu/utk_gradthes/316.

Feuz, D.M. and Umberger, W.J. 2001.Consumer willingness to payfor flavor in beef steaks: An experimental economics approach. Agricultural Economics, University of Nebraska-Lincoln, Paper 30.

Goldberg, I. and Roosen, J. 2005. Measuring consumer willingness to pay for a health risk reduction of salmonellosis and campy lobacterosis. Paper prepared for presentation at the $11^{\text {th }}$ Congress of the European Association of Agricultural Economist, Copenhagen, Denmark, August 24-27, 2005

Halbrendt, C. Sterling, L., Snider, S. and Santoro, G. 1995. Contingent valuation of consumers' willingness to purchase pork with lower saturated fat. In: J. Caswell (Ed.) Valuing food safety and nutrition. Chap.15, pp. 319-339.

Huang, C., Kan, K. and Fu, T. 1999. A generalized binary-ordinal probit model of consumer willingness to pay for food safety in Taiwan. J. of Con. Aff., 33: 76-91.

Islam, M.H, Hashem, M.A., Hossain, M.M., Islam, M.S., Rana, M.S. and Habibullah, M. 2012. Present status on the use of anabolic steroids and feed additives in small scale fattening in Bangladesh. Prog Agri 23 (1-2): 1-13.

Kijlstra, A and Eijck, I.A.J.M. 2006. Animal health in organic livestock systems. Netherland J. of Animal Sci. 54 (1): 77-94.

Latvala, T. 2011. Risk, information, and trust in the food chain: Factors explaining consumer willingness to pay. Int. J. of Food Sys. Dyn., 1(4), 295Ğ304

Millock, K., Hansen, L.G., Wier, M. and Anderson, L.M. 2002. Willingness to Pay for Organic products: A Comparison between Survey Data and Panel Data from Denmark ,AKF Denmark.

Napolitano, F., Girolami, A., and Braghieri, A. 2009. Organic Meat: Market Development and Consumer Willingness to Pay, Nova Science Publishers, Inc.

Sandalidou, E., Baourkis, G. and Siskos, Y. 2002. Customers' perspectives on the quality of organic olive oil in Greece: A satisfaction evaluation approach. British Food J. 104(3/4/5):391-406.

Van Elzakker, B., Parrott, N. Chola Chonya, M. and Adimdao, S. 2007. Organic Farming in Africa in H. Willer and M. Yusseffi (Eds.) The World of Organic Agriculture: Statistics and Emerging Trends. Bonn, IFOAM, pp.96-106.

van Ravenswaay, E. and Wohl, J. 1995. Using contingent valuation methods to value the health risks from pesticide residues when risks are ambiguous. In: J. Caswell (Ed.) Valuing food safety and nutrition. Chap.14, pp. 287-317. 